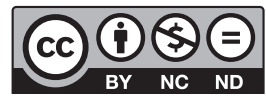

Estudos Teológicos foi licenciado com uma Licença Creative Commons Atribuição - NãoComercial - SemDerivados 3.0 Não Adaptada

http://dx.doi.org/10.22351/et.v59i1.3577

\title{
CRISE MIMÉTICA E VÍTIMA SACRIFICIAL. Contribuição de René Girard Para as teorias da Religião ${ }^{1}$
}

\author{
Mimetic crisis and sacrificial victim. \\ René Girard's contribution to the theory of religion
}

Os homens apressam-se mais a retribuir um dano do que um beneficio. Porque a gratidão é um peso. $A$ vingança, um prazer.

Tácito

\section{Frederico Pieper $^{2}$}

Resumo: A relação entre religião e violência, apesar de há muito discutida, tende a se reificar em duas posições extremas. De um lado, compreende-se que a religião, não obstante algumas atitudes violentas, tem como núcleo central um discurso e uma prática de paz. No outro extremo, há a associação muita rápida entre religião e violência, como se os termos fossem sinônimos. Tendo em vista a complexificação desse quadro, o presente artigo busca explorar as contribuições de René Girard, mostrando como ele se situa para além dessa polaridade, ao reconfigurar o lugar da violência no interior da religião. Para ele, de um lado, a violência é a alma e o coração da religião. Por outro lado, a religião visa à paz. Para entender essa aparente ambiguidade, o artigo explora as noções de desejo mimético e de vítima sacrificial. O artigo aponta como em Girard o desejo mimético conduz à exacerbação da violência e ao conflito. Para solucionar essa violência maior, recorrese à vítima sacrificial, cuja função é recriar, sob outras bases, a coesão social. Portanto a violência intrínseca à religião serve como meio para reestabelecer o convívio social. Com isso, o artigo procura indicar em que medida Girard assume a violência intrínseca à religião, ao mesmo tempo em que indica como ela pode conduzir à paz. Ao articular dessa maneira violência e paz, percebe-se como ele foge a posturas que negam uma ou outra face da religião, mas busca articular ambas.

Palavras-chave: Religião. Violência. Sacrifício. René Girard.

1 O artigo foi recebido em 06 de fevereiro de 2019 e aprovado em 21 de maio de 2019 com base nas avaliações dos pareceristas ad hoc.

2 Doutor em Ciências da Religião pela Universidade Metodista de Juiz de Fora e em Filosofia pela Universidade de São Paulo. Professor Adjunto na Universidade Federal de Juiz de Fora, Minas Gerais. Contato: fredericopieper@yahoo.com.br 
Abstract: The subject of the relationship between religion and violence, although long discussed, tends to reify in two extreme positions. On the one hand, religion is understood as a possible articulator of the promotion of peace and harmony. At the other extreme, there is the quick association between religion and violence, as if the terms were virtually synonymous. In view of the overcome this framework, the present article seeks to explore Girard's contribution, showing how it is situated beyond this polarity. For him, on the one hand, violence is the soul and heart of religion. On the other hand, religion is about peace. In order to understanding this apparent ambiguity, the article explores the notions of mimetic desire and sacrificial victim. The article points out how mimetic desire leads to exacerbation of violence and conflict in Girard's thought. In order to solve this greater violence, there is the recourse to the sacrificial victim, whose function is to recreate social cohesion on other grounds. Therefore, violence intrinsic to religion serves as a means to reestablish social interaction. Thus, the article seeks to indicate to what extent Girard assumes the violence intrinsic to religion, while indicating how it can lead to peace. By articulating violence and peace in this way, one notices how he escapes positions that deny one or the other face of religion.

Keywords: Religion. Violence. Sacrifice. René Girard.

\section{Introdução}

$\mathrm{O}$ vínculo entre religião e violência não é um tema desconhecido nos estudos de religião. Já há muito se explora essa vinculação, identificando-se, por exemplo, a violência no interior das tradições religiosas, a relação com temas correlatos (sacrifício, sofrimento, mal) a partir de diversas perspectivas analíticas, desde a filosofia até a literatura. ${ }^{3}$ Sendo um tema tão estudado e tão atual, como René Girard pode contribuir para pensá-lo? Para aqueles que já possuem alguma familiaridade com as ideias do pensador francês, a resposta à pergunta colocada pode soar óbvia. Os temas da violência e da religião, tratados de maneira bem peculiar em seu pensamento, são articuladores de sua reflexão. Dessa maneira, nada mais natural do que se ocupar de sua contribuição. No entanto, para além dessa razão mais geral, gostaria de mostrar a relevância de sua abordagem sobre o tema por motivos mais situados, especialmente atinentes aos desenvolvimentos recentes no âmbito da Ciência da Religião. Em outras palavras, esse texto busca explorar o vínculo entre violência e religião, focando na relação entre crise mimética e violência sacrificial, tendo em vista suas contribuições para a teoria da religião. Defende-se a hipótese de que Girard provê uma compreensão de religião que evita os extremos, de apenas considerá-la como fonte de todos os males ou apenas como promotora da paz. Nesse sentido, espera-se mostrar como ele contribui com uma noção mais complexa de religião.

3 O texto a seguir, por exemplo, ilustra bem essas várias possibilidades de abordagem do tema: JUERGENSMEYER, Mark; KITTS, Margo; JERRYSON, Michael. The Oxford Handbook of Religion and Violence. Oxford: Oxford University Press, 2015. 


\section{Religião e violência. Oscilando entre extremos}

A partir dos anos de 1960, aconteceram importantes alterações no campo da Ciência da Religião. Tomando como paradigma a fundação de vários importantes departamentos de Religious Studies nas principais universidades americanas, observou-se um duplo movimento. Na tentativa, contínua nessa área de estudos, de demarcar seu espaço em relação à teologia (e sua presença no paradigma da Religionswissenschaft que predominou no período anterior), a Ciência da Religião buscou aproximação das ciências sociais. A intenção era encontrar, nessas disciplinas, ferramentas metodológicas para a abordagem empírica da religião que a desvinculasse da teologia. Com isso, supunha-se assegurar a cientificidade que se julgava insuficiente no modelo anterior da Religionswissenschaft. Se esse encaminhamento resolve ou não o problema, quais seus alcances e limites, não é objeto para esse texto. Mas, concomitante a esse movimento, agendas de ordem prática acabaram por se infiltrar pelas portas dos fundos. Considerando as reivindicações pelos direitos civis na década de 1960, a contracultura e movimentos similares acabaram fornecendo elementos para a aplicação prática da Ciência da Religião. ${ }^{4}$ Assim, a questão dos direitos humanos, o diálogo inter-religioso, a promoção de uma cultura da paz etc. acabaram por se constituir como fim prático desse campo de estudos.

Podemos encontrar essa perspectiva na proposta de Friedrich Heiler. Num texto bastante conhecido, o autor defende que a Ciência da Religião, por meio do estudo comparado, pode encontrar aspectos recorrentes nas diversas tradições religiosas. Com isso, ela teria a finalidade de promover a convivência harmoniosa entre as religiões. Em seus próprios termos:

Uma das mais importantes tarefas da ciência da religião é lançar luz sobre essa unidade de todas as religiões [...] Qualquer que reconheça essa unidade deve assumi-la seriamente mediante a tolerância na palavra e na ação. Desse modo, a descoberta científica desta unidade requer uma realização prática e trocas amistosas e no esforço comum ético e social que os ingleses chamam de fellowship e cooperation ${ }^{5}$.

Ao encontrar essa unidade subjacente, a Ciência da Religião contribui para a superação dos preconceitos existentes, uma vez que uma tradição religiosa também se reconheceria na outra que, aparentemente, lhe soa tão diversa. Para além das diferenças, há elementos estruturantes que aproximam as visões de mundo religiosas. É como se, por detrás delas, houvesse uma única e mesma coisa. Uma vez reconhecida essa unidade de fundo, o caminho estaria aberto para o mútuo reconhecimento, tornando

4 WIEBE, Donald. Religious Studies. In: HINNELS, John. The Routledge Companion to the Study of Religion. London; New York: Routlegde, 2005. p. 111s.

5 HEILER, Friedrich. La historia de las religiones como preparación para la cooperación entre las religiones. In: ELIADE, M.; KITAGAWA, J. Metodología de la historia de las religiones. Barcelona: Paidós, 1996. p. 193. Nesse mesmo artigo, chama atenção que ao destacar a unidade da religião menciona sempre o amor, ignorando-se sua dimensão opressiva e violenta. Fala-se da fraternidade e do amor, mas se esquece que essa mesma divindade ordena matar e invadir. 
possível o diálogo e a convivência harmoniosa. Nessa linha, Heiler, por exemplo, defende que há sete princípios de unidade em todas as religiões. ${ }^{6}$ Curiosamente, se notamos os elementos que ele entende como constituintes dessa unidade, destacam-se os aspectos construtivos, especialmente a noção de amor à divindade ou ao próximo. Mas e a dimensão destrutiva da religião? Seria mero desvio? Haveria lugar para ela?

Em nosso contexto, essa percepção se fortalece com a presença do paradigma católico da teologia das religiões nos estudos sobre religião. Não se trata aqui de emitir juízo de valor, mas, de se perceber algumas consequências. A meu ver, por vezes, o ímpeto e a urgência do diálogo acabam gerando uma compreensão um tanto quanto linear da religião, sem captá-la em sua ambiguidade. ${ }^{7}$ Em alguns desses casos, ressaltam-se sobremaneira aspectos construtivos da religião e das tradições religiosas: sua dimensão de constituição de sentido, resposta ao desamparo, preocupação última ou ainda seu papel como agente na construção de uma convivência possível entre as diversidades. Mas se esquece ou não se dá a devida atenção ao fato de que religião é também desfundamentação, alienação e violência. Não se trata de dizer que essa perspectiva não reconhece certas feições violentas da religião. Elas são por demais pujantes para serem negadas. Há uma tentativa, que se revela mais sutil, que busca diferenciar as anomalias das religiões de suas manifestações mais autênticas. É como se em seu núcleo as religiões versassem sobre tolerância, amor e convivência com a diferença. A sua face violenta teria a ver com suas desfigurações, que não demonstram seu autêntico núcleo.

É muito curioso observar essa perspectiva quando se trata de figuras paradigmáticas das tradições religiosas. Apenas para citar dois exemplos. Como reação à articulação entre islã e terrorismo, Tariq Ramadan, professor na Universidade de Oxford, lançou em 2009 um livro que teve bastante repercussão: Nos passos do profeta. Numa passagem dessa obra, afirma:

Como a vida de Muhammad expressou a essência manifestada e experimentada da mensagem do islã, conhecer o Profeta é um meio privilegiado de adesão ao universo espiritual do islã. Desde o seu nascimento até a morte, a experiência do mensageiro - desprovida

6 1) A realidade do transcendente, do divino, do sagrado, do Outro, do verdadeiro ser. Por sobre as coisas passageiras, levanta-se o eterno, a ordem, o tao, o rtam, o logos. 2) Essa realidade transcendente é imanente aos corações humanos, visto que o espírito divino vive nas almas dos seres humanos. 3) Essa realidade é para o ser humano seu maior bem, a maior verdade, justiça, bondade e beleza. É o summum bonum. 4) Essa realidade do divino é o amor último que se revela aos homens e nos homens. 5) O caminho do homem até Deus é, universalmente, o sacrifício. 6) As religiões não ensinam somente o caminho até Deus, mas também até o próximo. As noções de amor e mesmo de humanidade aparecem em diversas tradições religiosas. 7) O amor é o caminho mais elevado para Deus (Cf. HEILER, 1996, p.178s).

7 Por exemplo, SMITH, Jonathan Z. The Devil in Mr. Jones. In: Imagining Religion: From Babylon to Jonestown. Chicago, IL: University of Chicago Press, 1982. p. 102-120; VALERA, Lúcio; LARA, Marco Antonio de. Bhagavad-Gītā: Cânone Para Paz ou Para Guerra? In: Numen: revista de estudos e pesquisa da religião, Juiz de Fora, v. 20, n. 1, p. 91-108; OLIVEIRA, Cláudio. Religiões e paz: Perspectivas teológicas para uma aproximação ecumênica das religiões. In: Horizonte, Belo Horizonte, v. 10, n. 27, p. 917-936, jul./set. 2012. 
de qualquer dimensão trágica humana - alia o chamado da fé, caminho entre as pessoas, a humildade e a busca pela paz com o Uno ${ }^{8}$.

Da mesma maneira, não é incomum destacar essa face com relação à figura de Jesus. Nesse sentido, por exemplo, destaca-se sua mensagem como expressão do amor por Deus, pelo próximo e pela alteridade, como se o núcleo de sua mensagem devesse ser interpretada a partir do signo do amor e da paz. ${ }^{9}$

Do ponto de vista da consciência religiosa, que se reflete em certas abordagens do fenômeno religioso, são comuns a idealização e o destaque a certos traços dessas figuras paradigmáticas. Poder-se-ia dizer que se trata de um recurso teológico. No entanto, é preciso considerar que isso se torna possível por meio da seletividade na leitura de textos fundadores. Aliás, para caracterizar essa hermenêutica, Antonio Carlos de Melo Magalhães evoca a figura do teólogo cristão Marcião, que, pela primeira vez, estabeleceu um conjunto de textos canônicos do cristianismo, excluindo o Antigo Testamento e partes consideráveis do Novo Testamento oficializado pela igreja:

Para mim, foi Marcião um verdadeiro clássico da teologia no sentido de fazer as perguntas mais relevantes, mesmo que não concorde com todas suas respostas; concordo plenamente com sua pergunta: o que fazer com as imagens cruéis e desgraçadas de Deus? Como reunir as imagens de profundo afeto com aquelas de profunda intolerância? Todos nós procuramos soluções marcionistas como: façamos uma seleção dos textos libertadores; fiquemos com o NT; não preguemos sobre os textos que falam da crueldade de Jahwé. Todas elas são soluções marcionitas ${ }^{10}$.

Além dessa seletividade na leitura dos textos normativos, para que essa idealização seja possível, faz-se necessário o isolamento da religião de outras esferas sociais, como os interesses econômicos, de poder ou sociais. Em outros termos, é como se a religião também não estivesse relacionada em rede a essas outras esferas sociais. $\mathrm{O}$ argumento aqui é de que os conflitos teriam conotação religiosa, mas seus reais motivos seriam de outra ordem. É como se as justificativas fossem religiosas, mas as motivações dos atos violentos não seriam realmente religiosas. ${ }^{11}$

8 RAMADAN, Tariq. In the Footsteps of the Prophet: Lessons from the Life of Muhammad. New York: Oxford University Press, 2009. p. 07.

9 Essa perspectiva já aparece num importante texto da modernidade, Carta sobre a tolerância de John Locke. Mais o início do escrito, afirma ele: "Se, como o Comandante de nossa salvação, desejassem sinceramente a salvação das almas, deveriam caminhar nos seus passos e seguir o perfeito exemplo do Príncipe da paz, que enviou seus discípulos para converter nações e agrupá-las sob sua Igreja, desarmados da espada ou da força [...]” (LOCKE, J. Carta sobre a tolerância. In: Locke. São Paulo: Abril, 1973. p. 04. (Coleção Os Pensadores). Para um exemplo mais recente, ver a produção do teólogo René Coste. Cf. RIBEIRO, Marcio. O desafio da paz. Contribuição das / às religiões: Alguns elementos iniciais. Atualidade Teológica, ano XV, n. 39, p. 583-596, set./dez. 2011.

${ }^{10}$ MAGALHÃES, Antonio Carlos. Violência, símbolo e religião. Relação entre monoteísmo e violência. Estudos de Religião, v. 21, n. 32, 2007. p. 19.

11 Por exemplo, LARSSON, J. P. Understanding Religious Violence: thinking outside the Box on Terrorism. London: Ashgate, 2004. CORNILLE, C. The Wiley-Blackwell Companion to Inter-Religious Dialogue. John Wiley \& Sons, 2013. 
Mas em que medida essa seletividade e esse isolamento não reforçam certas dicotomias ao invés de captar as ambiguidades da religião? Aqui reside a contribuição específica de Girard para esse debate. Em dissonância a essa leitura, ele entende que a violência não é uma derivação ou anomalia, mas é elemento estruturante da religião. Quer dizer: a violência não é uma perversão ou deturpação da religião. Antes, a religião é intrinsicamente violenta. Nos seus dizeres: "Nos universos míticos, o divino é um puro produto da violência mimética sobre o qual ele continua fundado: 'A violência é o coração e a alma secreta do sagrado""12.

Mas isso, como espero mostrar, não implica associações rápidas e generalizantes entre violência e religião, como tende a se tornar popular com certa literatura contemporânea que destaca uma simbiose entre religião e violência. Aliás, muitas dessas posturas críticas em relação à religião incorrem num problema de lógica. Algumas dessas aproximações contemporâneas da religião - que apesar de serem academicamente pouco consistentes alcançam grande público ${ }^{13}$ - têm sua razão e desempenham importante papel, especialmente como contraponto a fundamentalismos religiosos. Não há dúvidas que as religiões são também responsáveis por grande parte da violência, da dor, das guerras e das desgraças existentes no mundo. É importante que isso seja lembrado. Mas não é demais atribuir a elas a causa disso tudo, como se as coisas seriam realmente muito melhores sem as religiões? Afinal, se a religião surge justamente como resposta ao desamparo (Freud), à dor, ao sofrimento (Karl Marx), como ela pode ser causa de tudo isso a que ela quer responder? Se ela aparece para responder a essas indagações, como pode ela mesma ser a causa daquilo que lhe dá origem e sustentação?

Nesse sentido, a contribuição de Girard também parece adequada. Com isso, não pretendo dizer que há necessidade em se concordar com os pormenores de seus argumentos ou mesmo com o lugar privilegiado que ele concede ao cristianismo. Aliás, minha intenção aqui é muito mais ressaltar uma perspectiva de fundo, que me parece muito profícua para se pensar a religião. Em suma, nossa tarefa aqui consiste em modalizar e perceber o que significa que a violência é o coração do sagrado tendo em vista resgatar uma contribuição para as teorias da religião. Como se poderá observar, sua perspectiva, se ampliada também para o cristianismo, evita certas ingenuidades: de que a violência é uma deturpação da religião ou em conceber que religião como causa de todas as nossas mazelas, dentre elas, a violência.

12 GIRARD, R. Das coisas ocultas desde a fundação do mundo. Rio de Janeiro: Paz e Terra, 2009a. p.16.

13 Por exemplo, ONFRAY, Michel. Tratado de ateologia: física da metafísica. São Paulo: WMF Martins Fontes, 2007. O autor ressalta a pulsão de morte que marca as tradições monoteístas, principalmente o cristianismo. Por exemplo, "Os três monoteísmos, animados por uma mesma pulsão de morte genealógica, partilham uma série de desprezos idênticos: ódio da razão e da inteligência; ódio da liberdade; ódio de todos os livros em nome de um único; ódio da vida; ódio da sexualidade; das mulheres e do prazer; ódio do feminino; ódio do corpo, dos desejos, das pulsões. [...] Equivale a dizer a vida crucificada e o nada celebrado" (ONFRAY, 2007, p. 54). Sobre esse e outros autores, cf. PORTUGAL, A. C.; COSTA, A. L. F. O ateísmo francês contemporâneo: uma comparação crítica entre Michel Onfray e André Comte-Sponville. Horizonte, v. 8, n. 18, 2010. 
Além de ressaltar essa ambiguidade do religioso, ao apontar para como a violência é constitutiva dele, o pensador francês entende que uma antropologia (isto é, conhecimento do ser humano) não pode ser constituída abstendo-se de uma ciência do religioso. ${ }^{14}$ Desse modo, Girard se insere em regiões muito interessantes para nós. Em primeiro lugar, ele não vai aos extremos de conceber religião ou como pura alienação ou como pura harmonia. O religioso desempenha um importante papel nas sociabilidades e, portanto, deve ser compreendido evitando-se reducionismos. A radicalização de alguns pressupostos de Emile Durkheim tem como consequência indicar como a cultura e as instituições, no limite, se radicam no religioso. Isso é interessante para a Ciência da Religião. Afinal, além de propor importante articulação entre religião e violência, Girard não busca compreender o religioso como uma esfera secundária, mas desloca o religioso como condição para se entender as instituições sociais e a cultura.

E ainda, por fim, estamos diante de um pensador interdisciplinar. Mais do que se entrincheirar em um campo de estudos, Girard tem uma indagação. Por isso mesmo é difícil classificar esse historiador de formação: crítico literário, antropólogo, filósofo, teólogo, psicólogo, cientista da religião? Todas são designações possíveis e nenhuma delas cobre os múltiplos territórios aos quais sua intuição inicial o conduz.

\section{Teoria mimética e violência}

A teoria girardiana sobre a religião se forma a partir da leitura de grandes romancistas. Ao iniciar sua vida acadêmica, coube a ele lecionar sobre grandes clássicos da literatura europeia em universidades americanas. Isso propiciou o contato com Cervantes, Flaubert, Dostoievski, Proust, Shakespeare ${ }^{15}$, dentre outros. A leitura desses grandes mestres, testemunhado pelo seu livro apenas recentemente traduzido para o português, Mentira romântica e verdade romanesca ${ }^{16}$, desperta seu interesse para um tema há muito presente no pensamento ocidental, mas ao qual não se havia dado a devida atenção: o desejo mimético (imitação).

O desejo mimético é a noção estruturante do pensamento girardiano. De certa maneira, sua reflexão é a exploração das consequências dessa noção básica. E nesse ponto se faz importante a atenção ao modo como muitas de suas noções são pensadas: o paradoxo. Nesse sentido, a mímesis é tanto agregadora como desagregadora. Todo o nosso processo de aprendizagem e de integração na cultura se dá via imitação. Uma criança aprende a comer à mesa observando como os adultos fazem. É lendo artigos científicos e imitando o modo como eles são feitos que aprendemos a escrever textos acadêmicos. Dessa maneira, a imitação permite a inclusão em um mundo de sentido. Pode-se dizer que, para Girard, o ser humano não aprende a imitar; antes, ele aprende

${ }^{14}$ GIRARD, 2009a, p. 23.

${ }^{15}$ GIRARD, R. Shakespeare e o teatro da inveja. Trad. Pedro Sette-Câmara. São Paulo: É Realizações, 2010.

${ }^{16}$ GIRARD, R. Mentira romântica e verdade romanesca. Trad. Lilian Ledon da Silva. São Paulo: É Realizações, 2009b. 
pelo imitar. É a mímesis que cria condições de habitarmos um mundo com sentido a partir de onde pensamos, agimos e falamos.

No entanto, a imitação não possui apenas essa função. Ela também é desagregadora. Para se referir a essa face da noção, ele emprega o termo mímesis, chamado inicialmente (à época das primeiras leituras dos romances) de triangularidade do desejo. Em que consiste essa noção? Esse triângulo envolve três elementos: objeto, modelo e sujeito. Diferentemente do que o pensamento romântico sustenta, não se trata de um sujeito autocentrado que deseja um objeto. Aliás, os escritores românticos justamente são esses que concebem o desejo como autossuficiente nos indivíduos independentes, como se o desejo não tivesse nenhuma relação com as circunstâncias. Isso ocorre, por exemplo, com a ideia de amor à primeira vista. $\mathrm{O}$ desejo pela outra pessoa aparece de modo individual, imediato e autônomo. Nessa concepção, o herói romântico é aquele que luta contra as adversidades externas que não somente não determinam esse desejo, como erguem obstáculos para impedi-lo.

No entanto, no modelo romanesco (que mais interessa a Girard), o desejo não surge isoladamente, mas passa sempre por um modelo. Nós desejamos aquilo que pessoas que admiramos (nossos modelos) desejam. Portanto o desejo não emerge de um sujeito autossuficiente que escolhe livremente aquilo que deseja. Esse eu, quando deseja, já está em relação com outros sujeitos. ${ }^{17}$ Por isso o desejo deseja segundo o desejo do outro. Em outros termos, o desejo é mediado pelo desejo de um outro. Por isso o desejo não se dá diretamente entre um sujeito que se direciona a um objeto. Mas o desejo é segundo o desejo de um outro. ${ }^{18}$ É nesse sentido que o modelo se configura como um mediador do desejo. Isso quer dizer que o sujeito desejante não deseja diretamente o objeto, mas o seu desejo passa por um modelo que desempenha um papel de mediador. A relação não é simétrica, uma vez que o modelo coloca-se acima do sujeito desejante.

Apenas para ilustrar, penso que vale a pena citar um exemplo explorado no início de Mentira romântica e verdade romanesca. Na leitura usual, Dom Quixote torna-se um soldado errante devido à loucura de habitar um mundo literário, quase que numa negação da realidade. No entanto, com isso não se percebe como a mímesis está aqui em operação por meio do desejo de imitar Amadis de Gaule. Leitor voraz que era dos textos de cavalaria, esse modelo acaba despertando nele o desejo. Ele

17 ANDRADE, Gabriel. René Girard: um retrato intelectual. São Paulo: É Realizações, 2011. p. 40ss.

18 Kojève, ao comentar a dialética do senhor e do escravo de Hegel, já apontava ideias muito similares. Por exemplo: "O homem, portanto, só pode aparecer na Terra dentro de um rebanho. Por isso a realidade humana só pode ser social. Mas, para que o rebanho se torne uma sociedade, não basta apenas a multiplicidade de desejos; é também preciso que os desejos de cada membro do rebanho busquem - ou possam buscar - os desejos dos outros membros. O desejo antropogênico (ser humano que reconhece sua individualidade, sua historicidade) difere do animal por buscar não um objeto real, mas um outro desejo, ou seja se quer ser desejado ou amado, reconhecido em seu valor humano [...] Do mesmo modo, o desejo que busca um objeto natural só é humano na medida em que é mediatizado pelo desejo de outrem dirigido ao mesmo objeto: é humano desejar o que os outros desejam, porque eles desejam [...]. A história humana é a história dos desejos desejados" (KOJÈVE, Alexander. Introdução à leitura de Hegel. Trad. Estela dos Santos Abreu. Rio de Janeiro: EDUERJ; Contraponto, 2002. p. 13). 
queria ser igual a Amadis. E por isso sai ao mundo. Portanto, para Girard, não se trata simplesmente de devaneio ou negação do real. Antes, é o desejo mimético que está aqui em operação. Nas palavras de Girard:

Dom Quixote renunciou em favor de Amadis à prerrogativa fundamental do indivíduo: ele não escolhe mais os objetos de seu desejo, é Amadis quem deve escolher por ele. $\mathrm{O}$ discípulo se lança em direção aos objetos que o modelo de toda cavalaria lhe indica, ou parece lhe indicar. Chamaremos esse modelo de mediador do desejo ${ }^{19}$.

No entanto, há um detalhe nessa relação entre Dom Quixote e Amadis. Uma vez que o cavaleiro modelo é uma peça da ficção literária dos textos de cavalaria, não há o risco de que ele seja encontrado pessoalmente pelo nosso cavaleiro errante. Em outros termos, o mediador e a pessoa mediada não estão no mesmo plano. Por isso mesmo essa mediação é externa. Em que importa esse detalhe? Uma vez que o desejo se direciona ao objeto via desejo alheio, ele pode se tornar um empecilho para o acesso ao objeto de desejo. Nessa obstrução reside o caráter potencialmente desagregador da mímesis. Uma vez que o modelo faz a mediação do desejo, ao imitá-lo ele pode vir a ser um entrave para a concretização do desejo. Ou seja, novamente vemos espécie de paradoxo: o modelo media, mas também bloqueia o acesso ao objeto do desejo, especialmente quando ele já possui o objeto que é desejado. Em outros termos, o modelo não é somente aquele que desperta o desejo, mas também é rival. No caso de Dom Quixote, esse conflito é minimizado. Uma vez que eles habitam mundos distintos, não há possibilidade de se tornarem efetivamente rivais. O modelo é um personagem de romance de cavalaria. Portanto o conflito não é uma ameaça real. Isso ocorre não somente nesse caso, mas pode ser ampliado para outros elementos. Quando há diferenças hierárquicas ou sociais muito bem demarcadas, de modo que o objeto de desejo se mostra por demais distante e inalcançável, acontece essa mediação externa.

No entanto, a situação se torna mais potencialmente violenta quando o mediador e o sujeito compartilham de um mesmo mundo, ou seja, quando não há um abismo os separando. Nesse caso, o desejo visa aos mesmos objetos. Uma vez que dois sujeitos que compartilham um mesmo mundo desejam um mesmo objeto ao mesmo tempo, eles se tornam rivais. Instaura-se uma competição entre eles. Esse processo no qual o modelo não é apenas imitado, mas se torna rival, é chamado de mediação interna.

Para ilustrar essa triangularidade do desejo, vale citar um exemplo. Em geral, os discentes tendem a tomar algum professor como modelo. Assumem alguns de seus costumes, de suas leituras, de suas ênfases etc. No entanto, eles podem se tornar rivais quando o discente busca reconhecimento acadêmico. Para isso, muitas vezes, tenta se diferenciar do antigo modelo, que, em condições de competitividade, se torna rival. Os corredores das nossas universidades estão cheios de histórias desse tipo. É interessante observar que essa rivalidade se mostra quando aquele que imita tenta se diferenciar do seu modelo. No entanto, não raramente, quanto mais ele tenta se afastar

19 GIRARD, 2009b, p. 26. 
do seu modelo, mais parecido ele parece aos olhos de outros. Há tentativa de se distanciar quando as diferenças parecem se apagar.

Para Girard, os romancistas entenderam melhor esse processo do que muitos críticos da modernidade ou mesmo os psicólogos. Eles não apenas chamaram a atenção para a mímesis, mas também é possível ler certo processo histórico subjacente. No mundo de Cervantes há hierarquias. O modelo está distante. O modelo de Dom Quixote, Amadis, sequer existe. Em não existindo, a rivalidade não se instaura. Já Dostoievski, Flaubert, Stendhal e Proust mostram justamente como esses modelos vão se aproximando na medida em que a burguesia defende, ao menos em tese, igualdade maior entre os indivíduos. Aqui o modelo já não se coloca distante, mas torna-se acessível ao compartilharem um mesmo mundo. A rivalidade se torna real. Ocorre aqui um processo histórico, em que há passagem da imitação externa para a imitação interna com o advento da modernidade.

A imitação se desenvolve até chegar a uma metafísica do desejo. O que ocorre aqui? "O objeto constitui-se apenas num meio de alcançar o mediador. É o ser desse mediador que o desejo almeja."20 Já não se trata de tomar o outro como mediador para o objeto de desejo, mas de desejar ser o mediador mesmo, isto é, de tomar o seu lugar. Nesse momento, instaura-se a rivalidade, e o caráter desagregador da mímesis se mostra ainda mais radicalmente. Até o passo anterior, a mímesis solidifica o compartilhamento de códigos e signos. Isso se rompe quando já não mais há satisfação em desejar segundo o desejo do outro, mas o desejo quer ser o outro. E para que um indivíduo possa se tornar o outro, seu modelo deve ser destruído. Nesse ponto, a mímesis revela seu caráter destrutivo. E mais, isso evidencia como a mímesis não é passiva. Pelo que se observou, já fica claro que mímesis não é apenas fazer o que outro faz. Aliás, não é gratuita ou absurda a desconfiança de muitos (dentre eles, Platão) com relação ao caráter desagregador da mímesis a ponto de expurgá-la da República. ${ }^{21}$ Ele sabia, talvez melhor do que nós, dos seus perigos por entender que mímesis vai muito além do que mera imitação de comportamentos. Ela contém em si potencial destrutivo.

É importante atenção a esse desenvolvimento. A mediação externa não é, por si mesma, desagregadora. A mediação interna (quando sujeito desejante e modelo compartilham de um mesmo mundo) conduz à rivalidade. Essa rivalidade pode ser mantida sob controle através de interditos ${ }^{22}$, por exemplo. No entanto, o desejo metafísico torna a rivalidade não mais administrável. Isso por diversas contradições internas: o sujeito desejante deseja o ser do outro. No entanto, ele nunca poderá satisfazer esse desejo completamente, afinal, ele nunca poderá ser o outro. Isso acaba gerando um

${ }^{20}$ GIRARD, 2009b, p. 77.

${ }^{21}$ GIRARD, 2009a, p. 28

${ }^{22}$ Que força é essa que leva o ser humano a renunciar àquilo que está mais disponível? Para ele, é o medo das rivalidades miméticas que conduz a esses interditos. Afinal, caso essas rivalidades sejam permitidas e aceitas, elas podem conduzir a uma violência sem fim. "Se os objetos interditos são sempre os mais próximos e os mais acessíveis, é porque eles são os mais suscetíveis de provocar rivalidades miméticas entre os membros do grupo" (GIRARD, 2009a, p. 100). 
sujeito desejante ressentido. Um exemplo disso? As páginas de $O$ homem do subsolo de Dostoievski revelam a natureza desse indivíduo.

O trabalho de crítico literário de Girard o conduzira até aqui: a mediação interna e o desejo metafísico desembocam num estado de rivalidade e de violência. $\mathrm{O}$ passo seguinte nos direciona para a pergunta por algum mecanismo capaz de manter essa violência sob controle a fim de que a convivência em grupo seja possível. Como a coesão é factível nessas condições de acirramento da rivalidade?

\section{O mecanismo vitimário}

A teoria da mímesis e seu caráter conflitivo, por vezes, aparecem na história do pensamento. Numa parte fundamental do Leviatã, justamente quando caracteriza o estado de natureza como luta de todos contra todos, Thomas Hobbes diz: "Portanto se dois homens desejam a mesma coisa, ao mesmo tempo, que é impossível ela ser gozada por ambos, eles tornam-se inimigos. E no caminho para seu fim [...] esforçam-se por se destruir ou subjugar um ao outro" ${ }^{\text {23 }}$. No caso de Hobbes, a solução para esse estado de guerra de todos contra todos - que gera uma vida solitária, pobre, sórdida, embrutecida e curta - é um ato da razão no qual todos concordam em abdicar de seus direitos, transferindo-os a uma terceira pessoa.

Se e até onde o paralelo com Hobbes é válido, em Girard as coisas se processam de modo diferenciado. A solução é inconsciente (portanto não se pauta num cálculo) e, por mais paradoxal que possa parecer, a situação de violência é resolvida por um ato violento, ainda que em proporções menores. Quando a rivalidade ascende a um estágio tal que ameaça a coesão, surge a figura denominada de bode expiatório (vítima emissária): toda a violência é projetada sobre um indivíduo ou grupo, que passa a ser visto como responsável por aquele estado desagregador. ${ }^{24}$ Ao invés de luta de todos contra todos, instaura-se a luta de todos contra um. Assim, a situação de rivalidade não se resolve por um ato da razão tendo em vista o contrato social, mas por um ato de violência com dimensões claramente religiosas, no qual todos se unem contra um, restaura-se certa condição de coesão. Esse sacrífico, que une antigos inimigos na execução da ameaça compartilhada, tem por efeito restaurar (ao menos temporariamente) uma situação de equilíbrio. Uma vez que o antigo culpado restaura a comunidade, ele transita entre a acusação e a elevação ao estatuto de sagrado. Em termos bem sucintos, percebe-se como a coesão social funda-se numa violência sacrificial a fim de controlar uma violência maior. Exploremos alguns traços daquilo que se denomina de bode expiatório. Afinal, é aqui que encontramos um vínculo fundamental entre o sagrado e a violência.

Para nos resguardarmos de uma compreensão simplificadora do que está em jogo na resolução da crise mimética, deve-se considerar a particularidade ambígua da mímesis. Na crise mimética, o que importa é a rivalidade. Aqui o objeto é prescindido,

${ }^{23}$ HOBBES, Thomas. Leviatã. São Paulo: Nova Cultural, 1999. I. XIII, p. 74. (Coleção Os Pensadores).

${ }^{24}$ GIRARD, R. O bode expiatório. São Paulo: Paulus, 2004. p. 34. 
de modo que o mais importante passa a ser ocupar o lugar do outro. O objeto, que antes mobilizava a mímesis agregadora, agora tem sua relevância diminuída até sumir do horizonte. Afinal, o desejo não se dirige para o objeto, mas para o ser do modelo. Para se solucionar essa situação, a questão que se coloca é: como é possível retornar àquela situação de mímesis agregadora? Ora, é preciso que o objeto retorne. E como trazer o objeto de volta à cena? Em lugar da luta de um contra o outro, todos se unem contra um. A violência é canalizada contra o bode expiatório. Nessa situação, ao invés de se centrar na rivalidade, aquele que ataca o bode expiatório se torna modelo para os outros. Nessa nova situação, o objeto em direção ao qual seu desejo se dirige é o bode expiatório. Nota-se como aqui retorna o caráter agregador da mímesis. Ele é imitado e todos o seguem no ataque à vítima.

Nos ritos, que são reatualizações desse sacrifício, há casos em que todos participam da imolação. Mesmo nas situações em que se delega essa tarefa a um só indivíduo (como o sacerdote), ele o faz em nome de todos. Com isso, a unidade é reafirmada na oposição ao que deve ser sacrificado. Esse sacrifício não se dá sem haver insultos. Ela, a vítima, deve sofrer, afinal ela é responsabilizada por toda a crise mimética. "À oposição de cada um contra cada um sucede-se bruscamente a oposição de todos contra um. À multiplicidade caótica dos conflitos particulares sucede-se de repente a simplicidade de um antagonismo único: toda comunidade de um lado, e de outro a vítima." 25

No pensamento de Girard, há uma dupla transferência em operação. Em primeiro lugar, transfere-se a culpa para a vítima. Ela é insultada e tida como responsável pela desagregação e pela crise. No entanto, por meio de seu sacrifício, ela se torna agente da reconciliação. Assim, o sagrado se relaciona com essa dupla transferência, de modo que disso se depreende o caráter ambíguo dos deuses e do próprio sagrado. Aquele que era monstro se transforma em digno de respeito e admiração, torna-se separado (sagrado). Aquele que antes provocava temor, agora fascina. Nas palavras de Girard: "A volta à ordem e à paz está relacionada com a mesma causa que as perturbações anteriores, ou seja, com a própria vítima. É isso que leva a dizer que a vítima é sagrada. É isso que torna o episódio persecutório um verdadeiro ponto de partida religioso e cultural'"26. Um exemplo pode nos ajudar. Girard cita um mito recolhido aqui no Brasil.

Da grande casa da água, no país do sol, chegou, há muitos anos, um pequeno menino que cantava tão bem que os homens se reuniam a seu redor para escutá-lo. Ele se chamava Milomaki. Mas quando os homens que o haviam escutado voltavam para suas casas, e comiam peixe, eles morriam. Com o passar dos anos, Milomaki tornou-se um rapaz, mas ele tinha causado a morte de muitas pessoas se constituía um perigo. Todos juntos, os parentes das vítimas, queimaram-no numa grande fogueira. Em meio às chamas, Milomaki cantava maravilhosamente e, por fim, morreu. De suas cinzas surgiu a palmeira Paschiuba, cuja madeira serva para talhar as grandes flautas que reproduzem

\footnotetext{
${ }^{25}$ GIRARD, 2009a, p. 46.
}

${ }^{26}$ GIRARD, 2004, p. 75. 
o canto de Milomaki. Essas flautas são tocadas quando os frutos da palmeira estão maduros e se dança em homenagem a Milomaki. Foi ele quem presenteou essas coisas à comunidade. ${ }^{27}$

Em que medida essa narrativa se articula como caráter ambíguo do sagrado? De um lado, aparece a conduta negativa. Milomaki é agente da morte, afinal as pessoas morrem se ouvir seu belo canto após comerem o peixe. É uma ação individual e negativa. Em reação a isso, nota-se uma ação coletiva: seus parentes o queimam numa enorme fogueira. Com a sua morte, entretanto, a comunidade sai fortalecida, de modo que dançam em sua homenagem. Assim, parte-se de uma acusação, passando por seu sacrifício para, por fim, haver o reconhecimento do seu caráter sagrado.

Em consonância com isso, A violência e o sagrado argumenta que as instituições como festas, ritos de passagens, mesmo nossas ideias de lazer ou de educação, no limite, remetem aos ritos sacrificiais. ${ }^{28}$ Disso decorre que, em sua perspectiva, não há instituição cultural que não se radique no religioso. De certa maneira, acirra certa perspectiva de Durkheim, colocando o religioso na origem das instituições e vendo nele a possibilidade de manutenção da coesão. ${ }^{29}$ Portanto Girard não busca compreender o religioso a partir da sociedade ou da política, mas inverte sem cair numa "metafísica" ou se ver cativo da discursividade religiosa. Quando digo metafísica é simplesmente para dizer que ele não apela a alguma faculdade humana a priori ou mesmo a um sentimento inacessível. Antes, ele é bastante "iluminista" numa certa direção: não há enigma que não possa ser resolvido. Portanto não se trata de ver no religioso um mistério inacessível. Ele é racionalizável, mas nem por isso redutível a causas ou elementos não religiosos aos quais mais usualmente se recorrem.

Em suma, as culturas (e o que decorre disso) possuem uma base religiosa. Afinal, a religião é um tipo de violência menor que tem o intuito de proteger da violência descontrolada da mímesis. Dito de outra maneira, não é a religião que deve ser entendida a partir da sociedade, mas a sociedade é que se estrutura a partir da violência sacrificial religiosa, que faz a mediação e o controle das tendências destrutivas da mímesis. Não há desagregação via violência mimética, porque a violência do sagrado a canaliza via sacrifício.

Para que esse mecanismo vitimário possa funcionar, ele deve ser inconsciente. Desde a escolha da vítima até sua imolação, nada é planejado. Isso é perceptível nos relatos quando se observa que os perseguidores acreditam realmente que a vítima é culpada. Ou seja, não se percebe o desejo mimético em operação, mas acredita-se piamente que a vítima é culpada pela desagregação. Todo o mecanismo é camuflado, e,

${ }^{27}$ GIRARD, 2004, p. 136-137.

${ }^{28}$ GIRARD, R. A violência e o sagrado. Rio de Janeiro: Paz e Terra, 1998. p. 120s.

29 Textualmente, afirma: "Minha hipótese é mimética: é porque os homens se imitam uns aos outros mais do que os animais, que tiveram de encontrar um meio de conter a similitude contagiosa, capaz de produzir o puro e simples desaparecimento de sua sociedade. O sacrifício é o mecanismo que traz de volta a diferença onde todos haviam se tornado semelhantes entre si. O homem é produto do sacrifício. É, portanto, filho da religião" (GIRARD, R. Rematar Clausewitz: além da guerra. São Paulo: É Realizações, 2009c. p. 21). 
portanto, nos relatos persecutórios ou nos mitos, a vítima nunca pode aparecer como inocente, isto é, como não responsável pela desagregação. Não se reconhece no desejo mimético a raiz da violência. Mas é à vítima que se imputa toda a culpa. "Os perseguidores acabam sempre por se convencer de que um pequeno número de indivíduos ou até mesmo um só pode tornar-se extremamente nocivo para toda a sociedade, apesar de sua relativa fraqueza." ${ }^{30}$ Aqueles que condenam, perseguem e sacrificam estão totalmente convictos da transgressão da vítima. Caso se compreenda que a vítima nada mais é do que uma engrenagem no mecanismo vitimário do bode expiatório, que a real razão de sua morte é o desejo mimético, ela não mais funcionaria. Por isso os mitos apresentam as vítimas como efetivamente culpadas: Édipo matou o pai e se relacionou com a mãe. E, em decorrência disso, os mitos tendem a camuflar o mecanismo do bode expiatório. Eles omitem isso de modo não intencional. É a impossibilidade de perceber como o mecanismo do bode expiatório está aqui em operação como consequência da força desagregadora da mímesis que leva a esse encobrimento. Esse aspecto é tão fundamental que, para o pensador francês, a ruptura com essa lógica somente é possível quando se toma consciência da inocência da vítima. Nessa direção, ele reconhece certa novidade introduzida pelo cristianismo: aqui, pela primeira vez, reconhece-se o caráter inocente da vítima. Com isso, o mecanismo do bode expiatório é trazido à luz, revelando-se sua lógica.

Se a vítima não é culpada para ser condenada, mas é condenada para então se encontrar sua culpa, como se dá a escolha da vítima? ${ }^{31}$ A princípio, Girard destaca que essa escolha se efetua de modo aleatório. No entanto, mais recentemente, por meio da análise de mitos e relatos de perseguição, realça alguns traços estruturantes. ${ }^{32}$ No caso dos textos de perseguição, mas que são passíveis de encontrar paralelos nos mitos, os crimes são: violação criminal, acusação de perversões sexuais, crimes religiosos (profanação, por exemplo). Esses crimes possuem algo em comum. Eles questionam algum elemento que opera como diferenciador para estabelecer uma ordem: o ordenamento cultural, as disposições hierárquicas ou as diferenças familiares, dentre outras elementos de distinção. Quer dizer, eles questionam alguma diferença, mostrando a ameaça de se cair num estado de indiferenciação e, portanto, caótico.

Mais do que os crimes, é a ameaça da indiferenciação que determina os traços vitimários. No limite, há um sistema de classificação e ordenamento que se sente ameaçado por um indivíduo ou por um grupo. Ele se reconhece como relativo na medida em que casos lhe escapam. São justamente esses casos que não cabem no sistema classificatório de uma dada cultura que são os potenciais responsáveis, uma vez parecerem predispostos a cometerem crimes indiferenciadores. Por esse motivo,

\footnotetext{
30 GIRARD, 2004, p. 23.

31 Nas palavras de Girard: “A vítima é condenada de antemão, sem dúvida, ela não pode se defender, seu processo sempre já foi feito, mas é bem de um processo que se trata, iníquo o quanto quisermos, mas que não deixa de confessar sua natureza de processo. As bruxas são objeto de perseguições propriamente legais e até os judeus perseguidos são explicitamente acusados, acusados de crimes menos inverossímeis que os dos heróis míticos" (GIRARD, 2004, p. 50).

32 GIRARD, 2004, p. 22s.
} 
por exemplo, as marcas vitimárias se colocam nos extremos (feio ou bonito demais, rico ou pobre demais), minorias étnicas, religiosas etc., ou deficiências corporais. Em suma, as vítimas, efetivamente, não são culpadas por terem feito alguma coisa. Antes, elas são culpáveis na medida em que possuem algum traço vitimário que nada mais é do que a ameaça a um ordenamento da realidade.

Em suma, a religião tem início com uma crise de violência. Essa crise lança a busca por um culpado, como forma de deslocamento da mímesis da rivalidade para retornar ao objeto. Essa crise, gerada pelo acirramento da mímesis, é resolvida com uma violência menor, com o sacrifício de um culpado, que é elevado à categoria de sagrado. Esse mecanismo funciona porque é inconsciente. Isto é, os envolvidos atribuem a causa da crise à vítima, não suspeitando que ela poderia estar em outro lugar, no desejo mimético.

O passo seguinte, que não pretendemos explorar aqui, é a consciência de como esse mecanismo vitimário funciona. Se o mito esconde, para Girard, o cristianismo desvela o funcionamento desse mecanismo. Ele dá esse passo ao reconhecer a inocência da vítima. O problema dessa exceção está em postular que determinada tradição religiosa seria menos propensa à violência do que outras. Esse pressuposto leva a sustentar esse caráter exclusivo com base numa seletividade dos textos bíblicos, com uma hermenêutica bem peculiar. ${ }^{33}$ É possível reconhecer aqui certo tipo de marcionismo. Em geral, privilegiam-se textos que dão base para sua percepção, deixando de lado aqueles outros nos quais se indicam sacrifícios e violências recorrentes em outros sistemas religiosos. Mas, para nossos objetivos de mostrar como o vínculo entre religião e violência pode ser pensado para além de concepções extremadas, a compreensão do mecanismo do bode expiatório já é suficiente, ressaltando que não vemos argumentos suficientes para se sustentar algum caráter excepcional que o autor concede ao cristianismo. Mas isso será explorado em outra ocasião.

\section{Conclusão}

A partir desses elementos, podemos entender mais claramente o que Girard diz em Das coisas ocultas desde a fundação do mundo: "O religioso não é nada além desse imenso esforço para se manter a paz. O sagrado é a violência, mas se o religioso adora a violência, é porque considera que ela traz a paz; o religioso é inteiramente orientado para a paz, mas os meios dessa paz não são desprovidos de violência sacrificial" 34 . Ao mesmo tempo, fica também mais clara sua afirmação de que a violência constitui o coração do sagrado. Por meio de uma violência menor, a desagregação é evitada.

\footnotetext{
${ }^{33}$ Sobre isso, conferir, por exemplo, LOHFINK, Norbert. Deus e a violência: o Antigo Testamento à luz de René Girard. Revista portuguesa de Filosofia, Faculdade de Filosofia de Braga, Braga, LVI, p. 37-52, jan.jun. 2000.

${ }^{34}$ GIRARD, 2009b, p. 54. Em A violência e o sagrado, ele diz algo similar: "Afirmamos, portanto, que o religioso possui como objeto o mecanismo da vítima expiatória; sua função é perpetuar ou renovar os efeitos deste mecanismo, ou seja, manter a violência fora da comunidade" (GIRARD, 1998, p. 121).
} 
Mais do que compreensão da obra de Girard, cabe novamente ressaltar sua importância para certa complexificação teórica da religião no âmbito da Ciência da Religião. Mesmo que não se concorde com os pormenores dos argumentos de Girard, penso que há tentativa de superar certas interpretações polarizadas do vínculo entre religião e violência. De um lado, é evidente como a violência é constitutiva do religioso. Portanto a violência não é mera decorrência de um desvio da religião; mas ela é intrinsecamente marcada pela violência. No entanto, isso não significa cair no outro extremo. Girard não reduz a religião à violência ou faz da violência o fim último ao qual a religião conduz. A religião busca a paz, entendida aqui como coesão social. Não estamos, portanto, diante de uma abordagem teórica que articula de modo bastante profícuo violência e religião?

\section{Referências}

ANDRADE, Gabriel. René Girard: um retrato intelectual. São Paulo: É Realizações, 2011. CORNILLE, C. The Wiley-Blackwell Companion to Inter-Religious Dialogue. John Wiley \& Sons, 2013.

GIRARD, R. A violência e o sagrado. Trad. Martha Conceição Gambini. Rio de Janeiro: Paz e Terra, 1998. . O bode expiatório. São Paulo: Paulus, 2004.

. Das coisas ocultas desde a fundação do mundo. Rio de Janeiro: Paz e Terra, 2009a. . Mentira romântica e verdade romanesca. Trad. Lilian Ledon da Silva. São Paulo: É Realizações, 2009b. Rematar Clausewitz: além da guerra. São Paulo: É Realizações, 2009c.

2010 . . Shakespeare e o teatro da inveja. Trad. Pedro Sette-Câmara. São Paulo: É Realizações,

HOBBES, Thomas. Leviatã. São Paulo: Nova Cultural, 1999. (Coleção Os Pensadores).

HEILER, Friedrich. La historia de las religiones como preparación para la cooperación entre las religiones. In: ELIADE, M.; KITAGAWA, J. Metodología de la historia de las religiones. Barcelona: Paidós, 1996.

JUERGENSMEYER, Mark; KITTS, Margo; JERRYSON, Michael. The Oxford Handbook of Religion and Violence. Oxford: Oxford University Press, 2015.

KOJÈVE, Alexander. Introdução à leitura de Hegel. Trad. Estela dos Santos Abreu. Rio de Janeiro: EDUERJ; Contraponto, 2002.

LARSSON, J. P. Understanding Religious Violence: thinking outside the Box on Terrorism. London: Ashgate, 2004.

LOHFINK, Norbert. Deus e a violência: o Antigo Testamento à luz de René Girard. Revista portuguesa de Filosofia, Braga: Faculdade de Filosofia de Braga, LVI, p. 37-52, jan./jun. 2000. LOCKE, J. Carta sobre a tolerância. In: Locke. São Paulo: Abril, 1973. (Coleção Os Pensadores). MAGALHÃES, Antonio Carlos. Violência, símbolo e religião. Relação entre monoteísmo e violência. Estudos de religião, v. 21, n. 32, p. 12-21, 2007.

OLIVEIRA, Cláudio. Religiões e paz: Perspectivas teológicas para uma aproximação ecumênica das religiões. Horizonte, Belo Horizonte, v. 10, n. 27, p. 917-936, jul./set. 2012.

ONFRAY, Michel. Tratado de ateologia: física da metafísica. São Paulo: WMF Martins Fontes, 2007.

PORTUGAL, A. C.; COSTA, A. L. F. O ateísmo francês contemporâneo: uma comparação crítica entre Michel Onfray e André Comte-Sponville. Horizonte, v. 8, n. 18, 2010. 
RAMADAN, Tariq. In the Footsteps of the Prophet: Lessons from the Life of Muhammad. New York: Oxford University Press, 2009

RIBEIRO, Marcio. O desafio da paz. Contribuição das / às religiões: Alguns elementos iniciais. Atualidade Teológica, ano XV, n. 39, p. 583-596, set./dez. 2011

SMITH, Jonathan Z. "The Devil in Mr. Jones." In: Imagining Religion: From Babylon to Jonestown. Chicago, IL: University of Chicago Press, 1982. p. 102-120.

VALERA, Lúcio; LARA, Marco Antonio de. Bhagavad-Gītā: Cânone Para Paz ou Para Guerra? Numen: revista de estudos e pesquisa da religião, Juiz de Fora, v. 20, n. 1, p. 91-108.

WIEBE, Donald. Religious Studies. In: HINNELS, John. The Routledge Companion to the Study of Religion. London; New York: Routlegde, 2005 p. 243-258. 